\title{
Pengambilan Keputusan Petani Memilih Varietas Padi di Kecamatan Bangun Rejo Kabupaten Lampung Tengah
}

\author{
Decision Analysis of Farmers Choosing Varieties in Bangun Rejo \\ Sub-District, Central Lampung District
}

\author{
Oleh: \\ Ragil Ayu Mangesti ${ }^{1}{ }^{*}$, Helvi Yanfika ${ }^{1}$, Kordiyana K Rangga ${ }^{1}$ \\ Program Studi Penyuluhan Pertanian, Fakultas Pertanian, Universitas Lampung \\ Jl. Prof. Dr. Soemantri Brojonegoro No. 1 Bandar Lampung 35145, Lampung, Indonesia. \\ *e-mail: mragilayu@gmail.com
}

Received: March 05 2021; Revised: March 15, 2021; Accepted June 30, 2021

\begin{abstract}
ABSTRAK
Penelitian ini bertujuan untuk mengetahui tahapan pengambilan keputusan petani memilih varietas padi serta faktor-faktor yang mempengaruhi keputusan petani memilih varietas padi. Penelitian ini dilakukan di Kecamatan Bangun Rejo Kabupaten Lampung Tengah. Jumlah responden dalam penelitian ini adalah sebanyak 73 sampel. Data yang digunakan adalah data primer dan sekunder. Metode analisis data yang digunakan adalah analisis deskriptif dan kuantitatif melalui uji regersi linear berganda dan uji regresi sederhana. Hasil Penelitian menunjukan bahwa proses pengambilan keputusan memilih varietas padi oleh petani dilakukan melalui beberapa tahapan yaitu: tahap peningkatan pengetahuan (tahap awal dimana petani mengetahui adanya varietas padi Hibrida yang memiliki keunggulan), tahap persuasi (tahap dimana seorang individu membentuk sikap yang menguntungkan atau tidak menguntungkan terhadap inovasi), tahap keputusan (tahap dimana petani telah menentukan varietas padi mana yang lebih menguntungkan bagi dirinya), tahap implementasi (tahap ketika seseorang menggunakan inovasi), dan tahap konfirmasi (tahap dimana seseorang mencari penguatan atas keputusan yang telah dibuat). Keputusan petani memilih varietas padi dipengaruhi oleh faktor individu $\left(\mathrm{X}_{2}\right)$, faktor lingkungan $\left(\mathrm{X}_{2}\right)$, dan faktor ekonomi $\left(\mathrm{X}_{4}\right)$ sebesar 70,5 persen.
\end{abstract}

Kata kunci: Keputusan, Hibrida, Inhibrida, Produktivitas, Varietas.

\begin{abstract}
This study aims to determine the stages of decision making by farmers who choose rice varieties and the factors that influence farmers' decisions to choose rice varieties. This research was conducted in Bangun Rejo District, Central Lampung Regency. The number of respondents in this study was 73 samples. The data used are primary and secondary data. The data analysis method used is descriptive and quantitative analysis through multiple linear regression test and simple regression test. The results showed that the decision-making process for choosing rice varieties by farmers was carried out through stages: the stage of increasing knowledge (the initial stage where farmers have indicators of hybrid rice varieties that have advantages), persuasion stage (the stage where an individual forms a favorable or unfavorable attitude towards innovation), the decision stage (the stage where the farmer has determined the rice variety that is more profitable for him), the implementation stage (the stage where someone uses innovation), and the confirmation stage (the stage where someone looks for reinforcement of decisions that have been made). The decision of farmers to choose rice varieties by individual factors (X2), environmental factors (X2), and economic factors (X4) was 70.5 percent.
\end{abstract}

Keywords: Decision, Hybrids, Inhibrides, Productivity, Varieties. 


\section{PENDAHULUAN}

Padi merupakan tanaman pangan yang sangat penting di dunia setelah gandum dan jagung (Purnamaningsih, 2006). Masyarakat Indonesia menjadikan padi sebagai salah satu sumber makanan pokok dalam bentuk beras yang dikonsumsi sehari-hari. Ratarata konsumsi sebesar 111,58 kg per kapita per tahun dan total konsumsi nasional sebesar 22.280.000 ton per tahun (Timorria, 2019). Berbagai upaya telah dilakukan untuk meningkatkan produksi padi, tetapi masih belum dapat mencukupi kebutuhan beras nasional. Terjadi penurunan jumlah produksi beras sebesar 7,75 persen Penurunan produksi beras ini disebabkan adanya kemarau panjang serta belum optimalnya efisiensi budidaya yang dilakukan oleh petani (BPS, 2018).

Kecamatan Bangun Rejo adalah salah satu kecamatan yang ada di Kabupaten Lampung Tengah dan merupakan kecamatan dengan tingkat produktivitas padi tertinggi dengan produktivitas padi sebesar 53,59 ton/ha. Tingginya angka produktivitas ini dikarenakan petani yang telah mulai menerapkan teknologi untuk meningkatkan hasil produksi. Salah satu teknologi yang digunakan adalah penggunaan varietas benih padi unggul sebagai komponen produksi. Berdasarkan data oleh Dinas Pertanian Tanaman Pangan dan Hortikultura (2019) selama lima tahun terakhir petani di Kecamatan Bangun Rejo dominan untuk menanam varietas padi unggul Inhibrida. Tindakan memilih dan menggunakan varietas padi diawali dengan proses pengambilan keputusan.

Pengambilan keputusan dalam memilih varietas padi memiliki peranan yang sangat penting dalam kegiatan usaha tani. Hal ini karena varietas memberikan kontribusi terbesar dalam meningkatkan produksi padi yaitu 56.1 persen (Noviyanti, Kusmiyati, Sulistyowati, 2020). Pengambilan keputusan dipengaruhi oleh faktor lingkungan sosial, pendidikan, dan ekonomi. Varietas padi unggul Inhibrida memiliki potensi hasil panen mencapai 8-10 ton per hektar, tetapi berdasarkan data oleh Balai Penyuluhan Pertanian Kecamatan Bangun Rejo (2017) diketahui bahwa hasil panen padi yang diperoleh petani di Kecamatan Bangun Rejo adalah 4-5 ton per hektar. Berdasarkan hal tersebut diketahui bahwa terjadi kesenjangan antara potensi yang seharusnya dihasilkan dengan hasil yang diperoleh oleh petani, tetapi hal ini tidak mengubah keputusan petani untuk tetap menggunakan benih padi varietas Inhibrida sebagai input produksi dalam usaha taninya. Berdasarkan hal tersebut perlu dilakukan penelitian mengenai "Pengambilan Keputusan Petani Memilih Varietas Padi di Kecamatan Bangun Rejo Kabupaten Lampung Tengah" untuk mengetahui tahapan-tahapan pengambilan keputusan oleh petani dalam memilih varietas padi dan faktor-faktor yang mempengaruhi keputusan petani dalam memilih varietas padi.

\section{METODE PENELITIAN}

Penelitian ini dilakukan di Kecamatan Bangun Rejo Kabupaten Lampung Tengah. Penentuan lokasi penelitian dilakukan secara sengaja (purposive) dengan pertimbangan bahwa Kecamatan Bangun Rejo merupakan kecamatan dengan tingkat produktivitas padi tertinggi di Kabupaten Lampung Tengah. Penelitian dilakukan dengan menggunakan metode survei dan melibatkan sebanyak 73 responden. Jenis data yang digunakan dalam penelitian adalah data primer dan data sekunder. Data primer diperoleh melalui wawancara langsung dengan responden menggunakan kuesioner (daftar pertanyaan) yang telah dipersiapkan. Data sekunder diperoleh dari instansi yang terkait dengan penelitian seperti Badan Pusat Statistik, Dinas Pertanian Tanaman Pangan dan Hortikultura, dan Balai Penyuluh Pertanian Kecamatan Bangun Rejo. Responden dalam penelitian ini adalah petani padi yang tersebar di Desa Sidomulyo, Desa Sinar Luas, Desa Tanjung Jaya, dan Desa Tanjung Pandan. Jumlah populasi adalah sebanyak 
1.592 jiwa. Penentuan sampel merujuk pada Sugiarto (2003) sebagai berikut :

$n=\frac{N Z^{2} S^{2}}{N d^{2}+Z^{2} S^{2}}$

$1.592(1,96)^{2}(0,05)$

$\overline{1.592(0,05)^{2}+(1,96)^{2}(0.05)}$

\section{5,79}

$\overline{3,98+0,19}$

$=73$

Keterangan :

$\mathrm{n}=$ jumlah sampel

$\mathrm{N}=$ jumlah populasi petani padi

$\mathrm{d}=$ variasi sampel $(5 \%=0,05)$

$\mathrm{Z}=$ tingkat kepercayaan $(95 \%=1,95)$

$\mathrm{S}=$ derajat penyimpangan $(5 \%=0,05)$

Berdasarkan perhitungan diatas didapatkan jumlah sampel yang diperoleh sebanyak 73 responden, selanjutnya diambil jumlah responden secara proporsional mengacu pada Nazir (1988) dengan rumus sebagai berikut :

$\mathrm{ni}=\frac{N i}{N} \times 73$

$n 1=\frac{423}{1592} \times 73=19$

$n 2=\frac{302}{1592} \times 73=14$

$n 3=\frac{520}{1592} \times 73=24$

$n 4=\frac{347}{1592} x 73=16$

Keterangan :

n1= Jumlah sampel di Desa Sidomulyo

n2= Jumlah sampel di Desa Sinar Luas

n3= Jumlah sampel di Desa Tanjung Jaya

n4= Jumlah sampel di Desa Tanjung Pandan

Pengambilan sampel dilakukan dengan menggunakan simpel random sampling dengan menggunakan undian. Jumlah sampel untuk Desa Sidomulyo adalah sebanyak 19 petani dan jumlah sampel untuk Desa Sinar Luas adalah sebanyak 14 petani. Jumlah sampel untuk Desa Tanjung Jaya adalah sebanyak 24 petani dan jumlah sampel untuk desa Tanjung Jaya adalah sebanyak 16 petani. Metode analisis data yang digunakan dalam penelitian ini adalah analisis deskriptif dan kuantitatif. Analisis deskriptif digunakan untuk melihat tahapan pengambilan keputusan petani dalam memilih varietas padi. Analisis kuantitatif digunakan untuk mengetahui faktor-faktor yang mempengaruhi keputusan petani dalam memilih varietas padi. Analisis kuantitatif dilakukan dengan menggunakan uji analisis regresi linear berganda. Persamaan regresi linier berganda yang ditetapkan adalah sebagai berikut:

$$
\mathrm{Y}=\mathrm{a}+\mathrm{b} 1 \mathrm{X} 1+\mathrm{b} 2 \mathrm{X} 2+\mathrm{b} 3 \mathrm{X} 3+\mathrm{b} 4 \mathrm{X} 4+\varepsilon
$$

Keterangan:

$\mathrm{Y}=$ Keputusan petani memilih varietas

$\mathrm{a}=$ Koefisien konstanta

b1 $=$ Koefisien regresi

$\mathrm{X} 1=$ faktor individu

$\mathrm{X} 2$ = faktor lingkungan

$\mathrm{X} 3$ = faktor sosial

$\mathrm{X} 4$ = faktor ekonomi

$\varepsilon=$ Error, variabel gangguan

\section{HASIL DAN PEMBAHASAN}

\section{Keadaan Umum Responden}

Penelitian ini melibatkan responden sebanyak 73 petani padi yang terdapat di Kecamatan Bangun Rejo, Kabupaten Lampung Tengah. Responden merupakan petani padi yang tersebar di Desa Sidomulyo, Desa Sinar Luas, Desa Tanjung Pandan, dan Desa Tanjung Jaya dengan proporsional pengambilan sampel untuk Desa Sidomulyo sebanyak 19 petani, Desa Sinar Luas sebanyak 14 petani, Desa Tanjung Jaya sebanyak 24 petani, dan Desa Tanjung Pandan sebanyak 16 petani. Identitas responden dalam penelitian ini meliputi umur, tingkat pendidikan formal, dan luas lahan garapan.

Berdasarkan Tabel 1 diketahui bahwa sebagian besar responden berada pada rentang usia produktif dengan rentang usia 15-64 tahun. Sebesar 86,31persen berada pada rentang umur produktif dan 13,69 persen berada pada rentang umur tidak produktif selain itu, sebagian besar responden berada pada jenjang pendidikan 
Sekolah Menengah Pertama (SMP) dengan presentase sebesar 45,20 persen, dan sebanyak 31,50 persen responden berada pada jenjang pendidikan Sekolah Dasar (SD), sebesar 23,30 persen berada pada jenjang Sekolah Menengah Atas (SMA). Tingkat pendidikan akan mempengaruhi kemampuan petani untuk menangkap informasi yang diberikan.

Tabel 1.

Identitas responden

\begin{tabular}{cccc}
\hline & Klasifikasi & Jumlah & $\begin{array}{c}\text { Presentase } \\
(\%)\end{array}$ \\
\hline \multirow{3}{*}{ Umur } & 0-14 Tahun & 0 & 0 \\
& 15-64 Tahun & 63 & 86,31 \\
& $>$ 65 Tahun & 10 & 13,69 \\
\hline \multirow{3}{*}{ Pendidikan } & SD & 23 & 31,50 \\
& SMP & 33 & 45,20 \\
& SMA & 17 & 23,30 \\
\hline \multirow{3}{*}{ Luas lahan } & $0,50-1,00 \mathrm{Ha}$ & 44 & 60,27 \\
garapan & $1,01-1,50 \mathrm{Ha}$ & 15 & 20,55 \\
& $1,51-2,00 \mathrm{Ha}$ & 14 & 19,18 \\
\hline
\end{tabular}

Berdasarkan tabel di atas juga diketahui bahwa sebagian besar responden memiliki luas lahan dengan klasifikasi sempit yaitu sebesar 60,27 persen dan sisanya sebanyak 20,55 persen memiliki lahan dengan klasifikasi sedang, sebesar 19,18 persen memiliki lahan dengan klasifikasi luas. Hal tersebut diakibatkan karena luas lahan yang dibagi secara turuntemurun sehingga menyebabkan luas lahan yang dimiliki akan semakin sempit untuk setiap generasinya.

Tabel 2.

Klasifikasi varietas yang ditanam responden

\begin{tabular}{lcc}
\hline Varietas & $\begin{array}{c}\text { Jumlah } \\
\text { responden } \\
\text { (Jiwa) }\end{array}$ & $\begin{array}{c}\text { Rata-rata lama } \\
\text { penggunaan } \\
\text { (Tahun) }\end{array}$ \\
\hline Inhibrida & 64 & 12,09 \\
Hibrida & 9 & 10 \\
\hline
\end{tabular}

Berdasarkan Tabel 2 diketahui bahwa mayoritas responden lebih memilih menanam varietas Inhibrida. Sebanyak 80 persen responden menanam padi varietas Inhibrida. Beberapa jenis padi varietas
Inhibrida yang ditanam responden diantaranya yaitu: Inpari 30, Ciherang, Inpari 31, dan Mekongga. Varietas Inhibrida ini telah digunakan rata-rata selama 10-15 tahun. Terlihat bahwa petani lebih cenderung untuk memilih varietas Inhibrida karena varietas ini telah lama digunakan oleh petani. Lamanya penggunaan ini secara tidak langsung memberikan rasa kepercayaan petani terhadap varietas tersebut, sehingga mayoritas petani lebih memilih menggunakan padi varietas Inhibrida.

\section{Tahapan Pengambilan Keputusan Memilih Varietas Padi}

Terdapat beberapa tahapan yang dilakukan petani dalam menentukan keputusan untuk memilih varietas padi yang akan ditanam, diantaranya adalah sebagai berikut:

1) Peningkatan pengetahuan

Tahap ini merupakan tahap awal dimana petani mengetahui adanya varietas padi Hibrida yang memiliki keunggulan yaitu tingkat produksi dan potensi produktivitas yang lebih tinggi dibandingkan dengan varietas padi Inhibrida. Potensi hasil panen padi Hibrida dapat mencapai 12 ton per hektar dengan kualitas nasi yang lebih pulen dan wangi. Petani pada tahap ini mulai membuka diri terhadap adanya varietas padi Hibrida.

2) Persuasi

Tahap persuasi merupakan tahap dimana seorang individu membentuk sikap yang menguntungkan atau tidak menguntungkan terhadap inovasi. Tahap ini membagi petani menjadi dua kategori yaitu petani yang menunjukkan sikap tertarik terhadap padi Hibrida dan petani yang menunjukkan sikap tidak tertarik terhadap padi Hibrida. Petani akan mulai mencari informasi tambahan secara lebih rinci terkait keunggulan dan kelemahan dari varietas padi Hibrida. Pencarian informasi ini dilakukan melalui diskusi bersama 
Penyuluh, diskusi bersama petani lain dan diskusi bersama keluarga. Timbulnya sikap tertarik atau tidak tertarik ini dipengaruhi oleh beberapa faktor diantaranya harga benih, perawatan, hasil panen, dan harga jual gabah.

3) Keputusan

Tahap ini merupakan langkah keberlanjutan dari tahap persuasi. Keputusan yang diambil petani pada tahap ini merupakan hasil dari seluruh hal yang dipertimbangkan pada tahap persuasi. Petani telah menentukan varietas padi mana yang lebih menguntungkan bagi dirinya. Tahap ini membagi petani menjadi dua kategori yaitu petani dengan keputusan akan menanam padi varietas Hibrida dan petani dengan keputusan akan menanam padi varietas Inhibrida.

4) Implementasi

Tahap implementasi terjadi ketika seseorang menggunakan inovasi. Tahap ini membagi petani menjadi dua kategori yaitu petani yang memilih padi varietas Hibrida dan petani yang memilih padi varietas Inhibrida. Petani yang memutuskan memilih padi varietas Hibrida karena menilai bahwa varietas tersebut akan memberikan keuntungan yang lebih besar karena memiliki potensi hasil panen yang lebih tinggi sedangkan, petani yang memilih padi varietas Inhibrida menilai bahwa varietas inilah yang akan memberikan keuntungan yang lebih besar karena harga benih yang lebih murah dan perawatan yang tidak terlalu rumit akan menekan biaya produksi sehingga bisa menghasilkan keuntungan yang lebih besar.

5) Konfirmasi.

Tahap konfirmasi terjadi ketika seseorang mencari penguatan atas keputusan yang telah dibuat, tetapi ia dapat membalikkan keputusan sebelumnya jika mendapatkan pesan atau pengalaman yang bertentangan. Petani pada tahap ini akan saling bertukar informasi. Setelah menggunakan varietas yang dipilih petani akan mencari penguatan informasi lain apabila mereka menemukan ketidakcocokan selama menggunakan varietas tersebut. Adanya penilaian bahwa ternyata penanaman varietas Hibrida lebih rumit dari yang pernah dibayangkan. Memilih varietas Hibrida harus benarbenar memperhatikan perawatan karena varietas ini lebih mudah terserang hama dan penyakit

\section{Faktor-Faktor yang Mempengaruhi Pengambilan Keputusan Memilih Varietas Padi}

Faktor-faktor yang mempengaruhi keputusan petani memilih varietas padi diketahui melalui analisis regresi linear berganda dengan alat bantu SPSS 22 . Variabel bebas dalam penelitian ini adalah faktor individu $\left(\mathrm{X}_{1}\right)$, faktor lingkungan $\left(\mathrm{X}_{2}\right)$, faktor sosial $\left(\mathrm{X}_{3}\right)$, faktor ekonomi $\left(\mathrm{X}_{4}\right)$ dan variabel terikat dalam penelitian ini adalah keputusan petani memilih varietas padi (Y). Hasil regresi yang diperoleh untuk model fungsi keputusan petani memilih varietas padi dapat dilihat pada Tabel 3 .

\section{Tabel 3.}

Hasil regresi analisis faktor-faktor yang mempengaruhi keputusan memilih varietas padi

\begin{tabular}{lcll}
\hline \multicolumn{1}{c}{ Variabel } & Koefisien & Signifikan & VIF \\
\hline Konstanta & 27,914 & 0,000 & \\
Faktor individu $\left(\mathrm{X}_{1}\right)$ & 0,234 & 0,007 & 1,337 \\
Faktor lingkungan $\left(\mathrm{X}_{2}\right)$ & 0,326 & 0,001 & 2,552 \\
Faktor sosial $\left(\mathrm{X}_{3}\right)$ & 0,028 & 0,440 & 1,437 \\
Faktor ekonomi $\left(\mathrm{X}_{4}\right)$ & 0,399 & 0,000 & 1,855 \\
& & & \\
\hline F hitung & 40,661 & 0,000 & \\
R square & 0,705 & & \\
Adjusted R-Square & 0,688 & & \\
\hline
\end{tabular}

Berdasarkan Tabel 3 juga diketahui bahwa nilai $R$ Square adalah sebesar 0,705 . Hal ini mengartikan besarnya pengaruh keempat variabel independen yang meliputi variabel $\mathrm{X}_{1}$ (faktor individu), variabel $\mathrm{X}_{2}$ (faktor lingkungan), variabel $X_{3}$ (faktor sosial), variabel $\mathrm{X}_{4}$ (faktor ekonomi) terhadap keputusan petani 
dalam memilih varietas padi adalah sebesar 70,5 persen. Uji $\mathrm{t}$ dilakukan untuk mengetahui pengaruh dari masing-masing variabel independen terhadap variabel dependen. Uji $t$ dilakukan dengan melihat perbandingan nilai $t_{\text {hitung }}$ dan $t_{\text {tabel. }}$. Syarat pengambilan keputusan yaitu nilai $t_{\text {hitung }}>t_{\text {tabel. }}$. Berikut adalah perbandingan nilai $t_{\text {hitung }}$ dan $t_{\text {tabel }}$ untuk seluruh variabel pada penelitian ini.

Tabel 4.

Perbandingan nilai $t_{\text {hitung }}$ dan $t_{\text {tabel }}$

\begin{tabular}{lcc}
\hline \multicolumn{1}{c}{ Variabel } & $\mathrm{t}_{\text {hitung }}$ & $\mathrm{t}_{\text {tabel }}$ \\
\hline Faktor individu $\left(\mathrm{X}_{1}\right)$ & 2,805 & 1,997 \\
Faktor lingkungan $\left(\mathrm{X}_{2}\right)$ & 3,597 & 1,997 \\
Faktor sosial $\left(\mathbf{X}_{\mathbf{3}}\right)$ & $\mathbf{0 , 7 7 7}$ & $\mathbf{1 , 9 9 7}$ \\
Faktor ekonomi $\left(\mathrm{X}_{4}\right)$ & 4,134 & 1,997 \\
\hline
\end{tabular}

Berdasarkan Tabel 4 diketahui bahwa nilai thitung pada variabel faktor sosial lebih kecil dibandingkan dengan nilai $t_{\text {tabel }}$. Hal tersebut mengartikan bahwa faktor sosial tidak berpengaruh pada pengambilan keputusan petani dalam memilih varietas padi. Faktor sosial pada penelitian ini difokuskan pada tingkat kepercayaan responden terhadap informasi yang diberikan oleh orang lain. Faktor sosial dilihat berdasarkan pengaruh petani lain (yang sudah lebih dulu menggunakan varietas), pengaruh keluarga, dan pengaruh Penyuluh Pertanian Lapangan (PPL).

Faktor sosial tidak berpengaruh nyata terhadap pengambilan keputusan petani dalam memilih varietas padi di Kecamatan Bangun Rejo dikarenakan dalam memilih varietas yang akan ditanam petani lebih cenderung mempertimbangkan pada segi kebutuhan dan pengalaman dalam berusahatani. Kebutuhan dalam hal ini terkait pada kecenderungan memilih rasa aman (terhindar dari kegagalan panen) serta keinginan untuk memperoleh keuntungan lebih besar selain itu, rendahnya tingkat kepercayaan petani terhadap informasi yang diberikan oleh orang lain membuat petani tidak menjadikan saran atau pendapat dari orang lain sebagai pertimbangan yang kuat dalam menentukan varietas yang akan ditanam.

Adanya anggapan bahwa tidak semua pendapat bisa diterima, karena tidak semua petani menerapkan cara tanam yang benar sehingga petani lebih cenderung mempertimbangkan pengalaman dari hasil musim tanam sebelumnya. Beberapa hal tersebut yang melatarbelakangi tidak berpengaruhnya faktor sosial dalam pengambilan keputusan. Berdasarkan hasil penelitian diketahui bahwa dalam pengambilan keputusan petani memilih varietas padi dipengaruhi oleh faktor individu, faktor lingkungan, dan faktor ekonomi.

1) Faktor individu

Faktor individu merupakan pengaruh yang berasal dari dalam diri petani dalam mempertimbangkan varietas padi yang akan ditanam. Berdasarkan hasil penelitian diketahui bahwa petani lebih cenderung memilih varietas padi Inhibrida karena varietas ini memiliki gabah dengan bobot penuh dan dapat menghasilkan beras berwarna putih bersih selain itu, gabah padi Inhibrida tidak mudah patah/hancur saat digiling sehingga petani tidak mengalami penyusutan produksi yang besar.

Padi Inhibrida memiliki ketahanan yang cukup baik terhadap serangan hama dan penyakit. Hal tersebut menyebabkan petani memilih varietas Inhibrida sebagai input produksi dalam usahataninya. Hasil penelitian ini mendukung hasil penelitian terdahulu yang dilakukan oleh Siata (2016) yang menyatakan bahwa pemilihan varietas padi salah satunya dipengaruhi oleh faktor selera petani terhadap benih meliputi tingkat kepulenan, kebersihan benih, dan tidak berbau. Selaras dengan penelitian yang dilakukan Irsa, Nikmatullah, Rangga (2018) bahwa motivasi dapat meningkatkan usahatani.

2) Faktor lingkungan

Faktor lingkungan merupakan pengaruh yang berasal dari luar diri petani dalam mempertimbangkan varietas padi yang akan ditanam. Faktor lingkungan dalam penelitian ini dilihat berdasarkan tingkat kesesuaian kondisi lahan dengan varietas dan tingkat keramahan lingkungan varietas. Faktor lingkungan menjadi penting dalam kegiatan usahatani padi karena kondisi tanah 
yang sesuai akan membantu proses pertumbuhan padi dengan baik. Varietas Inhibrida dianggap sesuai dengan kondisi lahan garapan yang dimiliki oleh petani. Tekstur tanah yang berlempung mendukung pertumbuhan padi Inhibrida dengan baik, padi Inhibrida masih dapat tumbuh dengan baik meskipun tidak dilakukan olah tanah. Padi Inhibrida memiliki daya adaptasi lingkungan yang lebih baik dibandingkan dengan padi Hibrida. Padi Inhibrida masih dapat bertahan saat tergenang air meskipun produksinya menurun sedangkan padi Hibrida tidak tahan dan akan mengalami gagal panen. Varietas padi Inhibrida dinilai memiliki tingkat ketergantungan yang lebih rendah terhadap bahan-bahan kimia dibandingkan dengan varietas padi Hibrida. Hal tersebut dapat dilihat pada masa perawatan tanaman. Sejak masa awal semai hingga mendekati panen varietas padi Hibrida membutuhkan penyemprotan secara rutin. Pemberian pestisida pada proses penyemaian dilakukan untuk mencegah timbulnya jamur dan penyakit tanaman. Pemberian pestisida secara rutin setelah proses penanaman dilakukan untuk mengatasi serangan hama dan penyakit tanaman.

Hal ini dikarenakan varietas Hibrida lebih rentan terserang hama dan penyakit tanaman dibandingkan varietas Inhibrida selain itu, varietas Hibrida memerlukan pemupukan secara intensif untuk memberikan produksi yang optimal. Berbeda dengan padi varietas Hibrida, pada padi varietas Inhibrida pemberian pupuk yang telalu banyak justru akan menimbulkan penyakit pada tanaman ini. Pemupukan dan penyemprotan pada padi varietas Inhibrida disesuaikan dengan tingkat kebutuhan dan serangan dari hama atau penyakit tanaman. Karena pada dasarnya padi varietas Inhibrida lebih tahan terhadap serangan hama. Berdasarkan hal tersebut dapat dilihat bahwa tingkat ketergantungan padi varietas Inhibrida terhadap bahan-bahan kimia lebih rendah. Hal tersebut secara tidak langsung akan membantu menjaga kesehatan tanah.
Mengingat bahwa penggunaan bahan kimia yang terlalu berlebih akan merusak struktur tanah dan mengurangi unsur hara tanah.

3) Faktor ekonomi

Faktor ekonomi merupakan salah satu faktor yang menjadi pertimbangan penting dalam menentukan keputusan memilih varietas padi. Hal tersebut karena faktor ekonomi menjadi salah satu tujuan penting dari sebuah kegiatan usahatani. Faktor ini menjadi sangat penting bagi petani karena kecenderungan sifat petani yang tidak mau mengambil risiko menanggung kerugian dalam kegiatan usahatani yang dilakukannya. Harga benih padi varietas Inhibrida adalah Rp12.000,00 - Rp16.00,00 per kilogram sedangkan harga benih padi Hibrida adalah Rp150.000,00-190.000,00 per kilogram. Petani menilai dengan menggunakan varietas Inhibrida akan lebih menguntungkan. Hal tersebut karena dengan harga benih yang jauh lebih rendah petani dapat memperoleh produksi yang tidak jauh berbeda dengan padi Hibrida selain itu, gabah padi Inhibrida memiliki keunggulan tidak mudah hancur saat digiling sedangkan gabah padi Hibrida lebih mudah hancur saat digiling menjadi beras sehingga jumlah produksi varietas hibrida akan mengalami penurunan yang lebih tinggi dibandingkan dengan padi Inhibrida.

Hal ini menjadi pertimbangan tersendiri bagi tengkulak yang akan membeli gabah dari petani. Umumnya tengkulak akan mencari gabah padi varietas Inhibrida karena tidak banyak mengalami penurunan saat digiling menjadi beras. Gabah padi Inhibrida juga lebih mudah dipasarkan karena lebih banyak dicari oleh tengkulak. Namun, untuk gabah padi varietas Hibrida umumnya diproduksi karena sudah pesanan dari konsumen yang biasanya akan digunakan oleh rumah makan tetapi, jumlahnya tidak banyak karena tidak semua rumah makan menggunakan jenis padi Hibrida.

Berdasarkan tingkat kesesuaian harga dengan kualitas benih dan manfaat yang didapat serta perbandingan harga yang cukup jauh secara nyata menyebabkan 
petani menilai bahwa benih varietas Inhibrida lebih murah sehingga petani lebih memilih menggunakan padi varietas Inhibrida. Hasil penelitian ini mendukung penelitian terdahulu yang telah dilakukan oleh Rahmi dan Fadli (2017) yang menyatakan bahwa semakin mahal harga benih Hibrida yang dijual maka petani akan menggunakan benih non Hibrida.

\section{SIMPULAN}

Pengambilan keputusan dalam memilih varietas padi dilakukan dengan beberapa tahapan diantaranya tahap peningkatan pengetahuan, tahap persuasi, tahap keputusan, tahap implementasi, dan tahap konfirmasi. Pengambilan keputusan petani dalam memilih varietas padi dipengaruhi oleh faktor individu, faktor lingkungan, dan faktor ekonomi sebesar 70,5 persen. Faktor sosial tidak berpengaruh terhadap keputusan memilih varietas padi dikarenakan dalam memilih varietas yang akan ditanam petani lebih cenderung mempertimbangkan pada segi kebutuhan dan pengalaman dalam berusahatani.

\section{SANWACANA}

Ucapan terima kasih terutama ditujukan kepada keluarga dan teman-teman serta dosen pembimbing yang telah memberi arahan demi terselesaikannya penelitian ini. Ucapan terima kasih dapat juga disampaikan kepada pihak-pihak yang membantu pelaksanaan penelitian.

\section{DAFTAR PUSTAKA}

Badan Pusat Statistik. 2018. Perbandingan Produksi dan Konsumsi Beras di Indonesia.2018.Https://www.bps.go.id .Diakses pada tanggal 17 September 2020 pukul 07.21 WIB.

Balai Penyuluhan Pertanian Kecamatan Bangun Rejo. 2017. Kegiatan Peningkatan Produksi Padi Program Subsidi Benih Padi Inhibrida. Kantor
BPP Bangun Rejo. Bangun Rejo. Diakses pada tanggal 03 April 2020 pukul 11.30 WIB

Dinas Pertanian Tanaman Pangan dan Hortikultura Kabupaten Lampung Tengah. 2019. SP Padi 2019. Http://dptph.lampungtengahkab.go.id/. Diakses pada tanggal 17 September 2020 pukul 07.49 WIB.

Irsa, R., D, Nikmatullah., K, Rangga. 2018. Persepsi Petani Dan Efektivitas Kelompok Tani Dalam Program Upsus Pajale Di Kecamatan Banjar Baru Kabupaten Tulang Bawang Barat. JIIA, 6(1).

Nazir, M. 1988. Metode Penelitian. Ghalia Indonesia. Jakarta

Noviyanti, S., Kusmiyati., D. Sulistyowati. 2020. Adopsi Inovasi Penggunaan Varietas Unggul Baru Padi Sawah (Oryza Sativa L.) di Kecamatan Cilaku Kabupaten Cianjur Provinsi Jawa Barat. Jurnal inovasi penelitian, 1(4):771-782

Purnamaningsih, R. 2006. Induksi kalus dan optimasi regenerasi empat varietas padi melalui kultur in vitro. Jurnal Agrobio, 2(2):74-80.

Rahmi, H dan Fadli. 2017. Faktor-Faktor Yang Mempengaruhi Pengambilan Keputusan Petani Terhadap Penggunaan Benih Padi Di Kecamatan Nisam Kabupaten Aceh Utara. Jurnal Agrifo, 2(2).

Siata, R. 2016. Faktor-Faktor Yang Mempengaruhi Petani dalam Penerapan Benih Padi Varietas Ciherang di Desa Pudak Kecamatan Kumpeh Ulu. Jurnal Sosiohumaniora, 18(3):240-247.

Sugiarto, D. 2003. Teknik Sampling. PT Gramedia Pustaka Utama. Jakarta.

Timorria, I. 2019. Produksi Beras hingga September Diperkirakan Capai 26,91 Juta Ton. Https://ekonomi.bisnis.com. Diakses pada tanggal 16 September 2020 pukul 07.00 WIB. 